\title{
Sakera Seelok Dara "Sekolah Anak Pesisir Madura Sesuai Kearifan Lokal Budaya Madura" Sebagai Penguatan Pendidikan Non Formal Masyarakat Pesisir Pantai Madura
}

\author{
Ahmad Jamiul Amil ${ }^{1}$, Rika Wulandari ${ }^{2}$, Ayyu Subhi Farahiba ${ }^{1}$ \\ ${ }^{1}$ Program Studi Pendidikan Bahasa dan Sastra Indonesia, Universitas Trunojoyo Madura \\ ${ }^{2}$ Program Studi Penidikan Guru Sekolah Dasar, Universitaas Trunojoyo Madura \\ E-mail: ahmadamil@trunojoyo.ac.id \\ DOI: https://doi.org/10.21107/pangabdhi.v5i2.6115
}

Artikel Diterima : 12 Agustus 2019/ Revisi : 20 September 2019/Terbit : 19 Oktober 2019

\begin{abstract}
Abstrak
Pendidikan karakter sangat diperlukan sejak anak usia dini. Tanpa adanya pendidikan karakter menjadikan anak tumbuh kurang maksimal terutama dari segi moral dan akhlaknya. Berikut ini adalah hasil identifikasi permasalahan yang dialami oleh anak-anak pesisir antara lain: 1) Sebagian besar anak yang tumbuh tanpa didikan dan kasih sayang dari orangtua kandung mengalami masalah dalam perkembangan sosialnya yaitu suka memukul, bertindak agresif sesuai kehendak hati tanpa mengetahui baik buruknya hal tersebut, 2) Beberapa anak pesisir masih belum bisa membaca, menulis, dan berhitung padahal sudah berada di kelas atas, 3) Ada sebagian anak pesisir yang ternyata memiliki kemampuan di atas rata-rata/potensi pada pelajaran matematika yang dapat dikembangkan untuk mengikuti Olimpiade matematika namun karena kurangnya sarana prasarana yang mendukung dan perekonomian keluarga yang tidak mencukupi menyebabkan potensi tersebut tidak dapat diasah dengan baik. Dengan menjalin kemitraan bersama ini diharapkan mampu memaksimalkan potensi anak-anak pesisir melalui program Sekolah Anak Pesisir Madura Sesuai Kearifan Lokal Budaya Madura (SAKERA SEELOK DARA). Adapun Program yang akan dilaksanakan meliputi 1) Seminar Parenting "Pola Pengasuhan dan Pentingnya Penguatan Pendidikan Karakter Anak pada Abad 21" kepada orangtua anak-anak pesisir, 2) Pelaksanaan penguatan pendidikan karakter anak pesisir melalui pembiasaan positif untuk penguatan pendidikan karakter anak pesisir pada saat Bimbel bersama, serta Penyusunan dan Pengisian Buku Evaluasi dan Kontrol Pembiasaan Harian untuk penguatan pendidikan karakter anak pesisir. 3) Pelaksanaan bimbingan belajar dan pembinaan untuk pengembangan potensi anak-anak pesisir melalui kegiatan pemberian bimbingan belajar untuk mengasah keterampilan Calistung, pembinaan potensi anak pesisir melalui seni baca Qur-an (Qiro'atul Qur-an), serta pembinaan bagi anak-anak yang berminat mengikuti olimpiade dilakukan melalui pemberian bimbingan belajar persiapan mengikuti Olimpiade Matematika.
\end{abstract}

Kata kunci: Sakera Seelok Dara, Pendidikan Karakter, Penguatan Kompetensi Anak Pesisir

\section{PENDAHULUAN}

Kecamatan Modung merupakan salah satu kecamatan di daerah pesisir Pulau Madura yang memiliki jumlah cukup besar. Dari jumlah tersebut persentase terbesar adalah anak-anak usia sekolah dasar dan menengah pertama. Implikasi dengan adanya persentase jumlah penduduk usia sekolah dasar dan menengah pertama yang besar juga memberikan tanggung jawab yang cukup besar bagi pemerintah dan masyarakat Bangkalan untuk memberikan pendidikan yang memadai baik secara formal maupun nonformal, tidak terkecuali untuk penduduk yang berdomisili di sekitar pesisir pantai Madura. Penguatan terhadap Pendidikan Karakter Anak juga menjadi pekerjaan rumah besar bagi masyarakat Bangkalan karena akhirakhir ini banyak terjadi kasus kriminalitas yang dilakukan oleh anak usia sekolah di Madura. Keberadaan keluarga dan lingkungan yang baik dapat memberikan pengaruh positif terhadap perkembangan karakter anak. Namun sebaliknya, anak-anak yang kurang perhatian dari keluarga dan lingkungan masyarakat yang kurang baik dapat mengakibatkan anak-anak rentan untuk melakukan hal-hal yang buruk bahkan mengarah 
kepada tindak kriminalitas. Oleh sebab itu, menurut Sriwilujeng (2017:v) penguatan pendidikan karakter sangat perlu digalakkan saat ini karena melalui PPK dapat membentuk, mentransformasi, dan mengembangkan potensi peserta didik di seluruh Indonesia agar senantiasa berfikiran baik, berhati baik, dan berperilaku baik. Menurut Sriwilujeng (2017:7) penguatan pendidikan karakter penting untuk dilakukan salah satunya karena adanya revolusi digital yang semakin pesat dan telah mengubah sendi-sendi kehidupan, peradaban, pendidikan, dan termasuk juga kebudayaan. Tanpa adanya pondasi karakter yang kuat maka masyarakat akan dengan mudah tergerus oleh arus budaya baru yang masuk ke Indonesia.

Ada beberapa faktor yang mendorong anak melakukan tindakan yang bertentangan dengan norma atau kurang terpuji, salah satunya disebabkanoleh faktor ekonomi. Terdapat banyak anak pesisir yang kurang beruntung dari segi ekonomi. Hal ini menyebabkan sebagian besar dari mereka tumbuh tanpa perhatian dan kasih sayang orangtua dikarenakan orangtua sibuk bekerja ataupun sudah tiada di dunia ini. Padahal pendidikan yang pertama dan utama bagi seorang anak berasal dari keluarga terutama dalam pembentukan karakter. Pendidikan karakter sangat diperlukan sejak anak usia dini. Tanpa adanya pendidikan karakter menjadikan anak tumbuh kurang maksimal terutama dari segi moral dan akhlaknya. Hal ini sudah terbukti dari beberapa kasus yang sudah terjadi khususnya di daerah Madura yang menunjukkan kurangnya internalisasi pendidikan karakter dalam diri anak dikarenakan kurangnya perhatian orangtua maupun lingkungan terhadap tumbuh kembang anak seperti kekerasan (pemukulan siswa kepada guru hingga meninggal), pembegalan, pencurian, perampokan, penyalahgunaan obat-obat terlarang dan masih banyak lagi kasus kriminalitas yang terjadi juga melibatkan anak sebagai pelakunya.

Sebagian orangtua anak-anak pesisir di kecamatan Modung berprofesi sebagai buruh, pembantu rumah tangga, tukang cuci, pedagang dan kaum marginal. Kelompok ibu-ibu pengajian memberikan kebutuhan dasar, pendidikan dasar, kesehatan, serta bekal agama dengan tujuan agar anak-anak tersebut menjadi anak yang sehat jasmani, rohani dan berpendidikan walaupun hidup kekurangan.

Berikut ini adalah hasil identifikasi permasalahan yang dialami oleh anak-anak pesisir yang diasuh oleh kelompok ibu-ibu pengajian antara lain: 1) Sebagian besar anak yang tumbuh tanpa didikan dan kasih sayang dari orangtua kandung mengalami masalah dalam perkembangan sosialnya yaitu suka memukul, bertindak agresif sesuai kehendak hati tanpa mengetahui baik buruknya hal tersebut, 2) Beberapa anak pesisir masih belum bisa membaca, menulis, dan berhitung padahal sudah berada di kelas atas, 3) Ada sebagian anak pesisir yang ternyata memiliki kemampuan di atas ratarata/potensi pada pelajaran matematika dan sains yang dapat dikembangkan untuk mengikuti Olimpiade matematika atau sains namun karena kurangnya sarana prasarana yang mendukung dan perekonomian keluarga yang tidak mencukupi menyebabkan potensi tersebut tidak dapat diasah dengan baik. Perlu pendampingan dari ahli di bidang pendidikan untuk mengatasi masalah tersebut dikarenakan dari anggota kelompok pengajian tidak ada yang memiliki background dari pendidikan. Dengan menjalin kemitraan bersama ini diharapkan mampu memaksimalkan potensi anak-anak pesisir melalui program Sekolah Anak Pesisir Madura Sesuai Kearifan Lokal Budaya Madura (SAKERA SEELOK DARA).

Tujuan pengabdian ini Program SAKERA SEELOK DARA ini antara lain: pembekalan pengetahuan terkait pola pengasuhan untuk penguatan pendidikan karakter anak pesisir melalui Seminar Parenting.

\section{METODE}

1) Pembekalan pengetahuan terkait pola pengasuhan untuk penguatan pendidikan karakter anak pesisir melalui Seminar Parenting.

Tahapan Kegiatannya meliputi :

a. Identifikasi pola asuh sebagian besar masyarakat pesisir Madura di kecamatan Modung melalui wawancara dan observasi dengan penduduk pesisir

b. Menentukan Jadwal program pelaksanaan Seminar Parenting Pola Asuh yang akan dilaksanakan

c. Pelaksanaan Seminar Parenting dengan tema pola asuh anak pada masyarakat pesisir.

d. Pendampingan kepada masyarakat setempat 
2) Pelaksanaan penguatan pendidikan karakter anak pesisir melalui penyusunan program pembiasaan untuk penguatan pendidikan karakter anak pesisir pada saat mengikuti Bimbel serta Penyusunan dan Pengisian Buku Evaluasi dan Kontrol Pembiasaan Harian untuk penguatan pendidikan karakter anak pesisir.

Tahapan Kegiatannya meliputi :

a. Menentukan program pembiasaan untuk penguatan karakter anak pesisir

b. Penyusunan dan Pengisian Buku Evaluasi dan Kontrol Pembiasaan Harian untuk penguatan pendidikan karakter anak pesisir.

c. Pendampingan penguatan karakter

3) Pelaksanaan bimbingan belajar dan pembinaan untuk pengembangan potensi anak-anak pesisir melalui kegiatan pemberian bimbingan belajar untuk mengasah keterampilan Calistung, pembinaan bagi anak-anak yang berminat mengikuti olimpiade dilakukan melalui pemberian bimbingan belajar persiapan mengikuti Olimpiade Matematika.

Tahapan Kegiatannya meliputi :

a. Tim pengabdian memberikan pemantapan materi kepada mahasiswa KKN yang akan menjadi tutor dalam bimbingan belajar khususnya pada bimbingan belajar pemantapan Olimpiade Matematika

b. Menentukan pelaksanaan bimbingan belajar calistung, bimbingan belajar reguler dan bimbingan belajar untuk pemantapan olimpiade Matematika

c. Mengidentifikasi potensi akademik siswa pesisir melalui pemberian pretest untuk bimbingan pemantapan olimpiade Matematika dan bimbingan seni baca AlQuran.

d. Melaksanakan bimbingan secara intensif sesuai jadwal yang telah dibuat

e. Memberikan posttest setelah pemberian bimbingan belajar pemantapan olimpiade Matematika

f. Melakukan evaluasi kegiatan

g. Pengadaan Olimpiade Matematika untuk SD di pesisir kecamatan Modung yang diikuti oleh peserta (siswa-siswa SD/MI) dari desa Patereman, desa Karanganyar, dan desa Serabi Barat
4) Pembinaan potensi anak pesisir melalui seni baca Qur-an (Qiro'atul Qur-an).

Adapun tahapan yang dilakukan dalam kegiatan ini antara lain :

1. Menyusun program kegiatan bersama dengan tim untuk melaksanakan program seni baca Al-Qur'an.

2. Menentukan ustadz dan ustadzah yang nantinya akan menjadi tutor dalam baca seni Al-Qur'an yang memiliki background membaca Al-Qur'an yang baik dan benar.

3. Melaksanakan program seni baca AlQur'an secara intensif dan berkelanjutan untuk menguatkan karakter

4. yang dimiliki oleh anak pesisir Madura.

5. Melakukan kompetisi seni baca AlQur'an untuk memotivasi anak pesisir Madura dalam meningkatkan membaca Al-Quran.

\section{HASIL DAN PEMBAHASAN}

Pembekalan pengetahuan terkait pola pengasuhan untuk penguatan pendidikan karakter anak pesisir melalui Seminar Parenting. Peserta: Orangtua anak pesisir, khususnya di Kecamatan Modung, (Desa Patereman, Serabi Barat, dan Karanganyar). Waktu Pelaksanaan: 1 kali kegiatan. Lokasi: Aula Balai Desa Patereman. Peran mahasiswa KKN bersama-sama dengan tim pengabdian dan ibu-ibu pengajian/PKK mempersiapkan program kegiatan dan membantu pelaksanaan kegiatan. Pemateri utama adalah Dosen Psikologi yaitu Bapak Yudho Bawono, M.Psi.

Pelaksanaan penguatan pendidikan karakter anak pesisir melalui penyusunan program pembiasaan untuk penguatan pendidikan karakter anak pesisir pada saat mengikuti Bimbel serta Penyusunan dan Pengisian Buku Evaluasi dan Kontrol Pembiasaan Harian untuk penguatan pendidikan karakter anak pesisir. Metode Pelaksanaan dilaksanakan melalui Pendampingan. Waktu Pelaksanaan: setiap hari kegiatan bimbel dilaksanakan. Lokasi : Desa Patereman, Desa Serabi Barat, Desa Karanganyar. Peran mahasiswa KKN berkolaborasi dengan tim pengabdian memberikan penguatan dan pendampingan untuk pelaksanaan pendidikan karakter.

Pelaksanaan bimbingan belajar dan pembinaan untuk pengembangan potensi anakanak pesisir melalui kegiatan pemberian 
bimbingan belajar untuk mengasah keterampilan Calistung, pembinaan bagi anak-anak yang berminat mengikuti olimpiade dilakukan melalui pemberian bimbingan belajar persiapan mengikuti Olimpiade Matematika. Metode Pelaksanaan dilaksanakan melalui Bimbingan Belajar. Waktu Pelaksanaan: setiap hari mulai tanggal 15 Juli 2019 - 25 Juli 2019. Lokasi : Desa Patereman, Desa Serabi Barat, Desa Karanganyar. Langkah-langkahnya adalah sebagai berikut :

\section{(1). Pemantapan materi kepada tutor}

Tim pengabdian memberikan pemantapan materi kepada mahasiswa KKN yang akan menjadi tutor dalam bimbingan belajar khususnya pada bimbingan belajar pemantapan Olimpiade Matematika. Sebelum mahasiswa KKN memberikan pembimbingan untuk anakanak sekolah dasar yang berminat untuk mengembangkan kemampuan Olimpiade Matematika, mahasiswa yang tergabung dalam Tim Tutor Olimpiade Matematika dari tiga desa mengikuti pelatihan tutor sebagai wadah untuk penyamaan konsep dan persepsi yang dibimbing oleh dosen di tim pengabdian ini baik secara tatap muka maupun secara online di grup whatsapp. Mahasiswa dapat diskusi dalam grup apabila masih ada yang kurang dimengerti/dipahami sebelum memberikan matei pembimbingan kepada anak-anak SD. Tim pengabdian dari dosen menyiapkan buku ajar yang akan digunakan sebagai materi untuk disampaikan pada saat pembimbingan ke anak SD. Berikut ini adalah dokumentasi saat Tim Pengabdian dari dosen memberikan Pelatihan kepada Tutor/Mahasiswa yang akan memberikan pembimbingan kepada anak-anak SD.

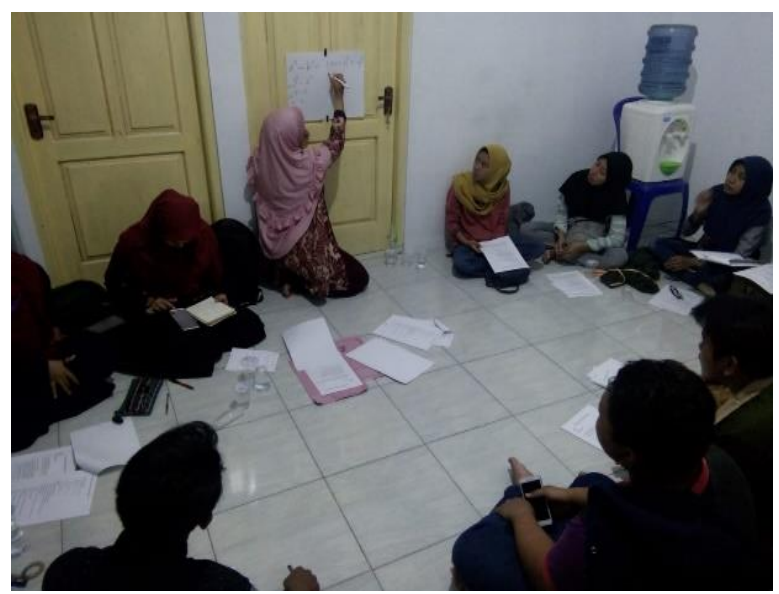

Gambar 1. Pelatihan Tutor Olimpiade oleh Dosen Tim Pengabdian

\section{(2). Menentukan pelaksanaan bimbingan}

Untuk menentukan pelaksanaan bimbingan belajar calistung, bimbingan belajar reguler dan bimbingan belajar untuk pemantapan olimpiade Matematika, mahasiswa melakukan koordinasi dengan tim pengabdian dan siswa-siswa SD untuk menentukan jadwal pelaksanaan bimbingan belajar. Penerjunan mahasiswa KKN pada saat liburan sekolah memberi dampak pada pelaksanaan program SAKERA SEELOK DARA ini yaitu kurangnya waktu untuk pembimbingan karena efektif pembimbingan baru dapat dilaksanakan pada tanggal 15 Juli 2019. Praktis proses bimbingan belajar dilaksanakan setiap hari baik bimbel reguler maupun Olimpiade.

\section{Mengidentifikasi potensi akademik siswa}

Proses mengidentifikasi potensi akademik siswa pesisir melalui pemberian pretest untuk bimbingan pemantapan olimpiade Matematika dan bimbingan seni baca Al-Quran. Pretest untuk mengetahui kemampuan awal anak-anak pesisir khuusnya di tingkat sekolah dasar dalam menguasai soal-soal Olimpiade Matematika memperoleh hasil yang kurang memuaskan, hampir $94 \%$ anak-anak pesisir masih belum memiliki kemampuan awal yang cukup memadai untuk dapat menyelesaikan soal-soal standar Olimpiade di ketiga desa tempat pengabdian. Namun demikian banyak siswa yang memiliki minat untuk mengikuti Olimpiade Matematika tetapi terkendala dengan anggaran untuk pembinaannya.

\section{Melaksanakan bimbingan secara intensif}

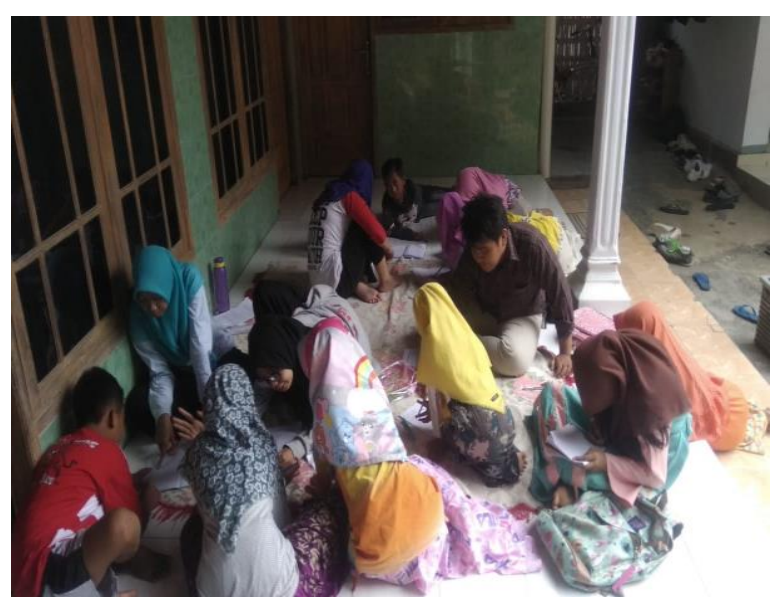

Gambar 2. Bimbingan Belajar Olimpiade di Desa Pesisir 
Pembimbingan dilakukan mulai tanggal 15 Juli 2019 di sore hari hingga malam setelah siswa SD pulang mengaji. Jumlah siswa SD yang mengikuti bimbingan belajar ini cukup banyak. Total ada sekitar 50 anak SD di ketiga desa pesisir Modung yang mengikuti bimbingan belajar reguler dan Olimpiade.

\section{Memberikan post-test}

Post-test dilakukan setelah pemberian bimbingan belajar pemantapan olimpiade Matematika. Setelah dilakukan pembinaan, diberikan posttest untuk mengetahui apakah ada peningkatan kemampuan/potensi akademik siswa yang mengikuti pembinaan/pelatihan bimbingan belajar Olimpiade Matematika.

Olimpiade Matematika ini dilaksanakan pada hari Minggu, 21 Juli 2019 diikuti oleh perwakilan dari masing-masing sekolah dasar yang ada di tiga desa pesisir Modung yaitu Patereman, Karang anyar dan Serabi Barat. Pelaksanaan Olimpiade Matematika dilakukan di SDN Patereman I. Siswa SD diberikan soal pilihan ganda sebanyak 40 soal dan soal uraian sebanyak 3 soal. Setelah waktu pengerjaan habis, dilakukan koreksi oleh tim Olimpiade dengan dikoordinasi langsung oleh tim pengabdian dari pihak dosen dan diperoleh 6 orang juara. Juara 1, II, III, Harapan I, Harapan II, dan Harapan III. Siswa sangat antusias mengikuti lomba.

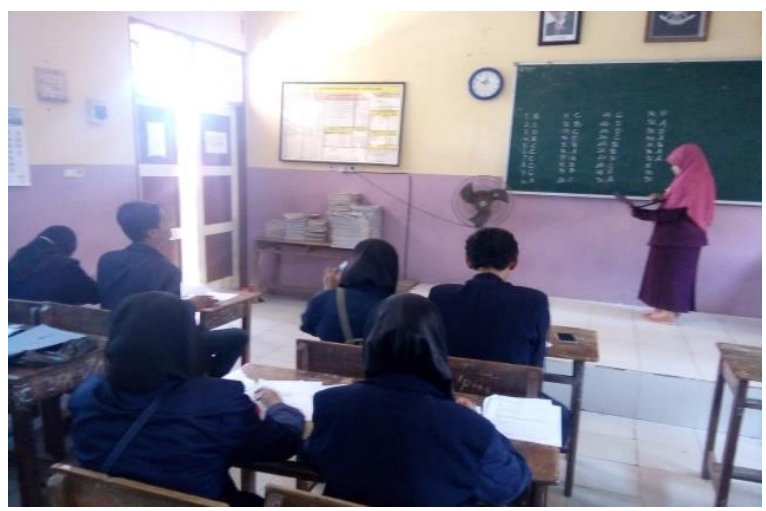

Gambar 3. Tim Olimpiade Melakukan Koreksi Bersama Dipandu oleh Tim Pengabdian

Pembinaan potensi anak pesisir melalui seni baca Qur-an (Qiro'atul Qur-an). Metode Pelaksanaan dilaksanakan melalui Kelompok Belajar. Waktu Pelaksanaan : dilaksanakan setiap hari (pelaksanaan bimbingannya), di akhir program KKN (Kompetisinya). Lokasi: Desa Patereman, Desa Serabi Barat, Desa Karanganyar. Adapun tahapan yang dilakukan dalam kegiatan ini antara lain :

1) Menyusun program kegiatan bersama dengan tim untuk melaksanakan program seni baca Al-Qur'an.

2) Menentukan ustadz dan ustadzah yang nantinya akan menjadi tutor dalam baca seni Al-Qur'an yang memiliki background membaca Al-Qur'an yang baik dan benar.

3) Melaksanakan program seni baca AlQur'an secara intensif dan berkelanjutan untuk menguatkan karakter yang dimiliki oleh anak pesisir Madura.

4) Melakukan kompetisi seni baca $\mathrm{Al}$ Qur'an untuk memotivasi anak pesisir Madura dalam meningkatkan membaca Al-Quran.

Peran mahasiswa KKN memberikan pelatihan kepada anak pesisir Madura dalam membaca seni Al-Quran yang sesuai dengan tajwid dan lafal yang benar. Tim pengabdian sebagai monitor dalam pelaksanaan kegiatan ini. Mahasiswa KKN diberikan kewenangan sepenuhnya dalam melaksakan kegiatan, termasuk juga ketika kompetisi membaca AlQuran.

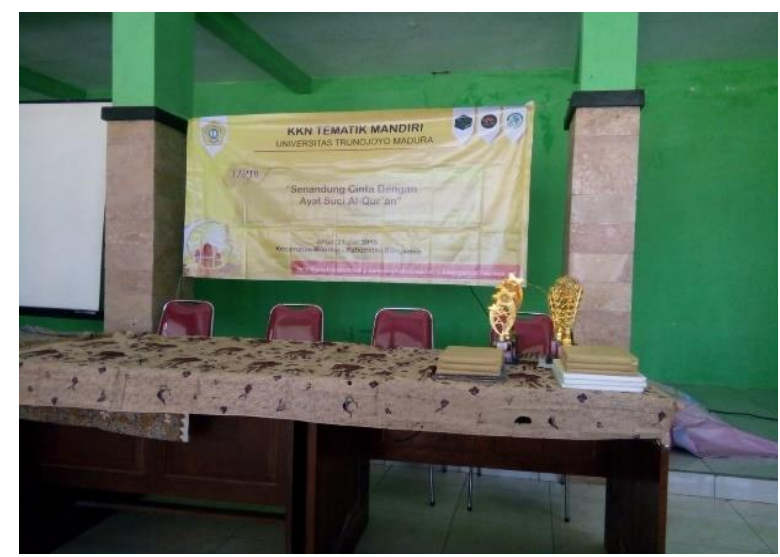

Gambar 4. Trophy bagi pemenang Olimpiade Matematika dan Lomba Seni Baca Al-Qur-an

\section{KESIMPULAN}

Pelaksanaan program "Sakera Seelok Dara" Sekolah Anak Pesisir Madura Sesuai Kearifan Lokal Budaya Madura Sebagai Penguatan Pendidikan Non Formal Masyarakat Pesisir Pantai Madura di wilayah pesisir Kecamatan Modung dilaksanakan melalui beberapa kegiatan antara lain: 1) Seminar Parenting "Pola Pengasuhan dan Pentingnya Penguatan Pendidikan Karakter Anak pada Abad 21" 
kepada orangtua anak-anak pesisir, 2) Pelaksanaan penguatan pendidikan karakter anak pesisir melalui pembiasaan positif untuk penguatan pendidikan karakter anak pesisir pada saat Bimbel bersama, serta Penyusunan dan Pengisian Buku Evaluasi dan Kontrol Pembiasaan Harian untuk penguatan pendidikan karakter anak pesisir. 3) Pelaksanaan bimbingan belajar dan pembinaan untuk pengembangan potensi anak-anak pesisir melalui kegiatan pemberian bimbingan belajar untuk mengasah keterampilan Calistung, pembinaan potensi anak pesisir melalui seni baca Qur-an (Qiro'atul Quran), serta pembinaan bagi anak-anak yang berminat mengikuti olimpiade dilakukan melalui pemberian bimbingan belajar persiapan mengikuti Olimpiade Matematika. Semua kegiatan terlaksana dengan baik walaupun sebenarnya dapat lebih optimal jika waktu untuk pembimbingan tidak terpotong liburan sekolah.

\section{DAFTAR PUSTAKA}

Anita. 2010. Pendidikan Karakter Berkearifan Lokal, Bangkalan: Jurnal Widyagogik UTM.

Busnowo. 2011. Media Pembelajaran Interaktif untuk Mengajarkan Konsep Berhitung Siswa Sekolah Dasar, Semarang: Jurnal Unnes. 
Volume 3, No. 1, April 2018 http://journal.trunojoyo.ac.id/pangabdhi

ISSN: 2477-6289 